\title{
Trends, Patterns and Correlates of Contraceptive Use among Kuwaitis, 1984-1999
}

\author{
Nasra M. Shah ${ }^{a}$ Makhdoom A. Shah ${ }^{b}$ Eqbal Al-Rahmanic \\ Jaafar Behbehania Zoran Radovanovic ${ }^{a}$ Indu Menona \\ aDepartment of Community Medicine and Behavioral Sciences, Faculty of Medicine, \\ bHealth Information Administration, Faculty of Allied Health Sciences and Nursing, and \\ cDepartment of Economics, College of Administrative Sciences, Kuwait University, Kuwait
}

\author{
Key Words \\ Family planning $\cdot$ Contraceptive methods $\cdot$ Arab $\cdot$ Kuwait
}

\begin{abstract}
Objective: To document the changes in trends and patterns of contraceptive use from 1984 to 1999 and analyze the sociodemographic correlates of contraceptive use. Methods: A nationally representative household survey of Kuwaiti women of reproductive age was conducted in 1999 and compared with published data from three earlier national surveys. Results: About $52 \%$ of Kuwaiti women were currently using some form of contraception and $79 \%$ had used it at some time in their life (ever-use). Three fourths were using a modern method of contraception at the time of the survey. Oral contraceptive pills were the leading method, followed by IUCDs. Oral contraceptive use declined from 79 to $45 \%$ in the period 1984-1999. Use of withdrawal increased from 2\% in 1987 to $11 \%$ in 1999 . Multivariate analysis indicated that a higher age and parity, a higher level of education of both spouses, urban residence, and a lower desired fertility were associated with higher contraceptive use. Conclusion: Contraception is generally used for spacing chil-
\end{abstract}

dren, with the wife being the main user. There is a continuing need to provide services and accurate information about the various methods of contraception.

Copyright @ 2001 S. Karger AG, Basel

\section{Introduction}

During the last few decades, most Arab countries have witnessed a trend towards declining fertility that has often been accomplished through the use of various contraceptive methods [1]. Some Arab countries have launched official family planning programs aimed at increasing the use of contraception, thereby reducing fertility. Examples include Egypt, Tunisia and Morocco, each of which has experienced a considerable fertility decline in recent years [2]. None of the six Gulf Cooperation Council countries (Bahrain, Kuwait, Oman, Qatar, Saudi Arabia, and United Arab Emirates) has an official family planning program [3]. However, fairly large percentages of women reported the use of some kind of contraceptive method, ranging from $62.1 \%$ in Bahrain to $23.8 \%$ in Oman in the mid-1990s [4].

\begin{tabular}{ll}
\hline KARGER & ( ) 2001 S. Karger AG, Basel \\
Fax +4161306 1234 & 1011-7571/01/0101-0034\$17.50/0 \\
$\begin{array}{l}\text { E-Mail karger@karger.ch } \\
\text { www.karger.com }\end{array}$ & $\begin{array}{l}\text { Accessible online at: } \\
\text { www.karger.com/journals/mpp }\end{array}$
\end{tabular}

Nasra M. Shah
Department of Community Medicine
Faculty of Medicine, PO Box 24923
13110 Safat (Kuwait)
Fax+965 533 8948, E-Mail nasra@hsc.kuniv.edu.kw 
In family planning literature, contraceptive methods are customarily grouped into two major categories, modern and traditional. Modern methods include oral contraceptive pills (OCPs), intrauterine contraceptive devices (IUCDs), condoms, sterilization, diaphragms, vaginal foams and spermicides. Traditional methods include rhythm, withdrawal, breast-feeding, and the use of herbs. The methods used for contraception vary among Arab countries. The use of traditional methods, such as withdrawal and prolonged breast-feeding, is much higher in some countries than in others. Among the modern methods, OCPs and IUCDs are the major ones that have been adopted in several countries. Also, female sterilization has become an important method in some countries such as Tunisia [5].

As Kuwait moves further along its path of development, it is undergoing important changes in contraceptive behavior, as indicated by national surveys conducted from 1984 to 1999 . The objectives of this study are to document the changes in the level of the use of contraceptive methods during the above period, examine the changes that occurred, and analyze the correlates.

\section{Subjects and Methods}

This study is based primarily on a household survey of 'Desired Fertility and Contraceptive Use' conducted during 1999, which was compared with three earlier national surveys [6-8] to ascertain any changes in trends, patterns and correlates of contraceptive use among Kuwaitis. The three earlier surveys consisted of representative samples of Kuwaiti households in which women of reproductive age (1549) who were married, widowed, separated or divorced (ever-married) were asked about their patterns of contraceptive use. Questions used in the previous surveys were fairly similar to the 1999 survey.

For the 1999 survey, a representative sample of 1,800 Kuwaiti households comprising $1.3 \%$ of the total Kuwaiti households was used. The Public Authority for Civil Information, which maintains a household and population register for the country, provided a list of 1,800 households chosen through a simple random selection. Within each household, we obtained a listing of all members and then selected the ever-married women up to 49 years of age as respondents eligible for an individual interview. Data were collected through a faceto-face interview conducted by trained Arab-speaking women during a visit to the respondent's house. A modified version of the Demographic and Health Survey (DHS) questionnaire was used for data collection. (The DHS is a worldwide program designed to collect data on fertility, family planning, and maternal and child health.)

Information was successfully collected from 1,689 (93.8\%) households, comprising 1,656 ever-married women. The remaining households could not be completed largely because the respondent or the head of household refused to participate in the survey. Of the 1,656 women interviewed, $1,502(90.7 \%)$ were married at the time of the survey. After comparing the contraceptive prevalence among all married women with previous surveys, this study concentrated on con- traceptive use among 1,232 currently married, nonpregnant, nonsterilized women who were exposed to the risk of pregnancy and therefore in possible need of contraception at the time of the survey.

The survey was restricted to Kuwaiti nationals, who comprise $35 \%$ of the total population. The majority (65\%) of Kuwait's population consists of expatriate migrant workers, most of whom are not accompanied by their families, and a majority is male [9]. While questions relating to contraceptive use and reproductive health are meaningful for Kuwaitis as well as non-Kuwaitis, the latter were beyond the scope of the present study.

Two types of contraceptive use were examined: A woman's lifetime use of contraception (ever-use) and her current use of a method at the time of the survey (current use). The level of contraceptive use was analyzed in relation to several demographic and social factors using bivariate as well as multivariate analysis. The characteristics of women using the main methods were also compared.

Differences between the characteristics of women were tested by $t$ test or ANOVA in the case of continuous variables, and by chi square in the case of categorical variables. A $p$ value of $<0.05$ was considered significant. Multivariate analysis of current-use methods was conducted by using logistic regression.

\section{Results}

The analysis pertaining to ever-use and current use was done for women of reproductive age (15-49) in each of the four surveys. In 1999, almost four fifths (79\%) of Kuwaiti women reported that they had at some time in their lives used a contraceptive method and more than half $(52 \%)$ of the married women reported that they were currently using one. Since the mid-1980s current use has increased by $13 \%$ (table 1). A marked change occurred from 1984 to 1999 in the mix of methods used for contraception (table 2). The percentage of women using OCPs declined from 79\% in $1984-1985$ to only $45 \%$ in 1999 . Health concerns and fear of side effects appear to be important factors in disapproval of OCP use. Among the 1,502 married women, 577 (38\%) said they disapproved of using pills as a method to avoid or delay pregnancy. About one third of those who disapproved said that the use of pills makes people unable to have children, while $55 \%$ said that it causes side effects. The major side effects mentioned were headaches, dizziness, weakness, and water retention.

The percentage of those using traditional methods increased 4 times during the period 1987-1999, from 6 to $24 \%$. The percentage using withdrawal increased from $2 \%$ in 1987 to $11 \%$ in 1999 , while the use of condoms increased slightly from 4 to $6 \%$. The percentage of women using IUCDs also increased from 13 to $17 \%$ during the same period. Most methods used were reversible. Female sterilization also increased and was reported by 60 wom- 
Table 1. Ever-use and current use of any method, 1984-1999

\begin{tabular}{lcllll}
\hline Year & Reference & $\begin{array}{l}\text { Ever married } \\
\text { women in } \\
\text { survey }^{\mathrm{a}}\end{array}$ & $\begin{array}{l}\text { Ever use } \\
\%\end{array}$ & $\begin{array}{l}\text { Married } \\
\text { women in } \\
\text { survey }\end{array}$ & $\begin{array}{l}\text { Current use } \\
\%\end{array}$ \\
\hline $1984-1985$ & 6 & 2,015 & - & 1,700 & 39 \\
1987 & 7 & 4,175 & 56 & 3,962 & 35 \\
1996 & 8 & 3,453 & 73 & 3,089 & 50 \\
1999 & 10 & 1,656 & 79 & 1,502 & 52 \\
\hline
\end{tabular}

$-=$ Not available.

a Includes currently married, widowed, divorced and separated women.

Table 2. Major methods being used at time of survey among married, nonpregnant women, 1984-1999 (\%)

\begin{tabular}{|c|c|c|c|c|c|c|c|c|c|c|c|c|c|}
\hline \multirow[t]{2}{*}{ Year } & \multirow[t]{2}{*}{ Users } & \multicolumn{6}{|c|}{ Modern methods } & \multicolumn{5}{|c|}{ Traditional methods } & \multirow[t]{2}{*}{ Total, $\%$} \\
\hline & & pills & IUCD & $\begin{array}{l}\text { vaginal } \\
\text { methods }\end{array}$ & $\begin{array}{l}\text { con- } \\
\text { doms }\end{array}$ & $\begin{array}{l}\text { female } \\
\text { sterili- } \\
\text { zation }\end{array}$ & subtotal & rhythm & $\begin{array}{l}\text { with- } \\
\text { drawal }\end{array}$ & $\begin{array}{l}\text { breast- } \\
\text { feeding }\end{array}$ & subtotal & $\begin{array}{l}\text { any } \\
\text { other } \\
\text { method }\end{array}$ & \\
\hline 1984-1985 & 315 & 79.0 & 12.6 & - & - & 4.0 & 95.6 & - & - & - & - & 4.4 & 100.0 \\
\hline 1987 & 1,369 & 69.6 & 10.6 & 1.3 & 4.2 & 5.9 & 91.6 & 4.7 & 1.5 & - & 6.4 & 2.0 & 100.0 \\
\hline 1996 & 1,553 & 57.5 & 13.6 & 0.4 & 5.8 & 4.3 & 81.3 & 8.5 & 6.9 & 1.5 & 18.6 & 0.0 & 100.0 \\
\hline 1999 & 774 & 45.0 & 16.9 & 0.1 & 5.6 & 7.8 & 75.5 & 7.8 & 10.9 & 5.8 & 24.4 & 0.1 & 100.0 \\
\hline
\end{tabular}

en, comprising $8 \%$ of the current users, while just 1 single husband was sterilized.

Table 3 shows the association during the year 1999 of several socioeconomic status and other characteristics with ever-use and current-use methods among married, nonsterilized and nonpregnant women who were at risk of conception. The level of ever-use contraception was significantly higher in women aged 30-49 years who were nonnomadic (non-Bedouin), had 3 or more children, desired relatively fewer children, or whose husband was educated than those women who did not know the number of children their husbands wanted or did not know his opinion about contraception.

In terms of current contraceptive use, the women's age showed a curvilinear association. Current use increased among women in their 30s and declined among those who were 40-49. Non-Bedouin ethnicity, participation in the work force, urban residence, relatively higher parity, lower desired fertility, and higher education each had a significant positive association with the current use of any method. The husband's opinion seemed to affect the wife's contraceptive behavior very strongly, since the level of contraceptive use was highest among those women whose husbands approved of such use and wanted fewer children than their wives. About $76 \%$ of the women whose husbands approved of contraception reported current use of a method compared with only $19 \%$ of women whose husbands did not approve of contraception.

Logistic regression analysis of current use was conducted for married, nonpregnant and nonsterilized women $(n=1,232)$ as shown in table 3. Current use was defined as 1 and nonuse as 0 . The results of this analysis are shown in table 4. In view of the curvilinear association of current-use and age, a squared term for age was added to the regression analysis. It was found that the wife's age, parity, the educational level of the husband as well as the wife, and residence in urban areas were significantly and positively associated with current use. Also, current use was significantly higher among couples where the wife reported that the husband wanted fewer children than her compared with women who did not know their husband's desired fertility.

Current use of various methods differed according to some sociodemographic characteristics of the respondents, as shown in table 5. On average, women who were using OCPs were significantly younger than those who 
were using an IUCD or other modern methods. The time of initiating contraceptive use differed significantly and users of traditional methods initiated contraception at relatively lower parity than those using other methods. The former started using a traditional method after an average of 1.45 children compared with pill users who started after they had an average of 1.78 children.

The average educational level of the husband as well as the wife was lower among pill users and users of traditional methods compared with those who were using an IUCD or another modern method. The average level of education completed by the husband was exceptionally high among those who were using methods such as condoms, injections, or diaphragms. Also among users of the above methods, the husband approved of contraception in $100 \%$ of the cases compared with $86 \%$ of those cases where the couple was using a traditional method.

Ethnicity and place of residence were also significantly associated with the method currently being used. The percentage of Bedouins was highest among those using the pill and lowest among those using other modern methods such as condoms, injections, or diaphragms (53 and 25\%, respectively). Similarly, the percentage of urban residents was highest (77\%) among those using condoms, injections, or diaphragms and lowest among the ones using traditional methods (44\%).

Several characteristics were not significantly associated with the method the respondent was using at the time of survey. These included parity, the number of sons or daughters at the time of initiating contraceptive use, number of children desired, whether the woman was working, and the type of housing the respondent was living in.

\section{Discussion}

At the end of the 20th century, 52\% of married Kuwaiti women of reproductive age were using a contraceptive method. Contraceptive prevalence was lower than for some Arab countries such as Lebanon and Tunisia, but higher than several others such as Egypt and Syria [11]. About three fourths of the Kuwaiti women were using a modern contraceptive method while the rest were using a traditional method such as withdrawal, rhythm or breastfeeding.

Among the modern methods of contraception, OCPs are still the major one. However, the relative importance of oral pills has declined substantially during the last two decades. Several possible reasons may account for the above trend. Health concerns of women are known to be
Table 3. Percent of ever-use and current use among currently married, nonpregnant, and nonsterilized women by selected socioeconomic status and other characteristics, $1999(\mathrm{n}=1,232)$

\begin{tabular}{|c|c|c|c|}
\hline & Women & Ever-use & Current use \\
\hline \multicolumn{4}{|l|}{ Age of woman } \\
\hline$<29$ years & 412 & $73.1^{* * *}$ & $58.7^{* * *}$ \\
\hline $30-39$ years & 488 & 87.9 & 66.4 \\
\hline $40-49$ years & 332 & 84.3 & 44.6 \\
\hline \multicolumn{4}{|l|}{ Ethnicity } \\
\hline Bedouin & 595 & $78.7 * *$ & $54.3^{* *}$ \\
\hline Non-Bedouin & 631 & 84.6 & 61.3 \\
\hline \multicolumn{4}{|l|}{ Woman's work status } \\
\hline Working & 829 & 81.1 & $67.2 * * *$ \\
\hline Not working & 403 & 83.1 & 53.4 \\
\hline \multicolumn{4}{|l|}{ Type of housing } \\
\hline Villa and part of villa & 519 & 79.0 & 59.7 \\
\hline Middle income or flat & 255 & 81.6 & 59.2 \\
\hline Low income or annex & 449 & 84.6 & 55.2 \\
\hline \multicolumn{4}{|l|}{ Area of residence } \\
\hline Urban & 618 & 83.2 & $63.3^{* * *}$ \\
\hline Rural & 614 & 80.3 & 52.6 \\
\hline \multicolumn{4}{|l|}{ Living children } \\
\hline $0-2$ & 329 & $54.7 * * *$ & $40.4^{* * *}$ \\
\hline $3-5$ & 584 & 92.6 & 69.2 \\
\hline $6+$ & 319 & 89.7 & 55.5 \\
\hline \multicolumn{4}{|l|}{ Living sons } \\
\hline $0-2$ & 781 & $76.7 * * *$ & $55.7 *$ \\
\hline $3+$ & 451 & 90.5 & 61.9 \\
\hline \multicolumn{4}{|l|}{ Living daughters } \\
\hline $0-2$ & 821 & $77.0^{* * *}$ & 57.1 \\
\hline $3+$ & 411 & 91.2 & 59.6 \\
\hline \multicolumn{4}{|l|}{ Desired fertility } \\
\hline 5 and below & 530 & $84.9 *$ & $67.7 * * *$ \\
\hline 6 and above & 509 & 79.4 & 54.4 \\
\hline \multicolumn{4}{|l|}{ Education of woman } \\
\hline Illiterate & 185 & 76.2 & $41.6^{* * *}$ \\
\hline Below secondary & 406 & 81.0 & 57.1 \\
\hline Secondary and above & 641 & 83.8 & 63.2 \\
\hline \multicolumn{4}{|l|}{ Education of husband } \\
\hline Illiterate & 96 & $71.9^{* *}$ & $32.3^{* * *}$ \\
\hline Below secondary & 460 & 78.5 & 53.7 \\
\hline Secondary and above & 675 & 85.3 & 64.4 \\
\hline \multicolumn{4}{|c|}{ Number of children husband wants according to wife } \\
\hline Same as the wife & 508 & $82.9^{* * *}$ & $61.4^{* * *}$ \\
\hline More than the wife & 400 & 84.3 & 58.5 \\
\hline Less than the wife & 63 & 96.8 & 71.4 \\
\hline Don’t know & 259 & 72.6 & 47.5 \\
\hline \multicolumn{4}{|c|}{ Husband's opinion of contraception } \\
\hline Approves & 861 & $96.2^{* * *}$ & $75.6^{* * *}$ \\
\hline Disapproves & 248 & 54.0 & 19.4 \\
\hline Don’t know & 118 & 33.9 & 10.2 \\
\hline
\end{tabular}

${ }^{*} \mathrm{p}<0.05 ;{ }^{* *} \mathrm{p}<0.01 ;{ }^{* * *} \mathrm{p}<0.001$ using chi square. 
Table 4. Logistic regression analysis of current contraceptive use among married, nonsterilized, and nonpregnant women $(\mathrm{n}=1,232)$

\begin{tabular}{|c|c|c|c|}
\hline & $\mathrm{B}$ & Significance & $\begin{array}{l}\text { Odds of } \\
\text { current use }\end{array}$ \\
\hline Age of woman & 0.2099 & 0.006 & 1.23 \\
\hline $\mathrm{Age}^{2}$ & -0.0047 & 0.000 & 0.99 \\
\hline Number of living children & 0.4085 & 0.000 & 1.50 \\
\hline Education of woman & 0.0637 & 0.001 & 1.07 \\
\hline Education of husband & 0.0467 & 0.008 & 1.04 \\
\hline Living in urban area & 0.4430 & 0.004 & 1.56 \\
\hline Non-Bedouin ethnicity & 0.1874 & 0.251 & 1.21 \\
\hline Respondent working & 0.2510 & 0.139 & 1.29 \\
\hline Living in middle-income residence or villa & -0.1695 & 0.282 & 0.84 \\
\hline \multicolumn{4}{|l|}{ Husband's number of desired children } \\
\hline Not known (ref. category) & - & - & - \\
\hline Same as wife & 0.3837 & 0.030 & 1.47 \\
\hline More than wife & 0.2926 & 0.111 & 1.34 \\
\hline \multirow[t]{2}{*}{ Less than wife } & 0.7963 & 0.022 & 2.17 \\
\hline & $\mathrm{R}^{2} \times 100$ & 23.8 & \\
\hline
\end{tabular}

Table 5. Comparison of sociodemographic characteristics of those currently using OCP, IUCD, other modern methods, or traditional methods, 1999

\begin{tabular}{|c|c|c|c|c|c|c|}
\hline Characteristics & $\mathrm{OCP}$ & IUCD & $\begin{array}{l}\text { Other } \\
\text { modern } \\
\text { methods }^{\mathrm{a}}\end{array}$ & $\begin{array}{l}\text { Traditional } \\
\text { methods }^{\mathrm{b}}\end{array}$ & $\begin{array}{l}\text { Current } \\
\text { use }\end{array}$ & $\mathrm{p}$ \\
\hline Women & 348 & 131 & 44 & 190 & 713 & \\
\hline $\mathrm{Age}^{\mathrm{c}}$ & 31.82 & 34.19 & 34.55 & 33.68 & 33.59 & $0.000^{\mathrm{d}}$ \\
\hline Living childrenc & 4.34 & 4.61 & 4.34 & 4.64 & 4.47 & $0.429^{d}$ \\
\hline Living sons ${ }^{\mathrm{c}}$ & 2.22 & 2.27 & 2.39 & 2.33 & 2.27 & $0.813^{\mathrm{d}}$ \\
\hline Living daughters ${ }^{\mathfrak{c}}$ & 2.12 & 2.34 & 1.95 & 2.31 & 2.20 & $0.279^{d}$ \\
\hline Level (grades) of education of wife $\mathrm{c}^{\mathrm{c}}$ & 10.40 & 11.07 & 12.70 & 10.30 & 10.64 & $0.019^{\mathrm{d}}$ \\
\hline Level (grades) of education of husband ${ }^{c}$ & 11.37 & 11.89 & 13.43 & 11.35 & 11.59 & $0.024^{\mathrm{d}}$ \\
\hline Children when first started ${ }^{c}$ & 1.78 & 1.73 & 1.61 & 1.45 & 1.74 & $0.002^{\mathrm{d}}$ \\
\hline Sons when first started ${ }^{c}$ & 0.98 & 0.95 & 0.93 & 0.80 & 0.96 & $0.391^{\mathrm{d}}$ \\
\hline Daughters when first started ${ }^{c}$ & 0.90 & 0.87 & 0.74 & 0.77 & 0.87 & $0.456^{\mathrm{d}}$ \\
\hline Desired children ${ }^{\mathrm{c}}$ & 5.20 & 5.16 & 5.0 & 5.33 & 5.25 & $0.697^{\mathrm{d}}$ \\
\hline Bedouin, $\%$ & 52.5 & 35.9 & 25.0 & 44.4 & 44.2 & $0.000^{\mathrm{e}}$ \\
\hline Working women, $\%$ & 63.5 & 55.7 & 52.3 & 65.8 & 63.8 & $0.142^{\mathrm{e}}$ \\
\hline Urban, $\%$ & 49.1 & 60.3 & 77.3 & 44.2 & 45.3 & $0.002^{\mathrm{e}}$ \\
\hline Living in villas, $\%$ & 36.2 & 50.4 & 44.2 & 35.8 & 39.2 & $0.472^{\mathrm{e}}$ \\
\hline Husband approves of contraception, $\%$ & 92.2 & 93.1 & 100.0 & 85.8 & 91.2 & $0.009^{\mathrm{e}}$ \\
\hline \multicolumn{7}{|c|}{ a Other modern methods include condoms, injections, foam jelly and diaphragm. } \\
\hline \multicolumn{7}{|c|}{ Traditional methods include periodic abstinence, withdrawal and prolonged breast-feeding. } \\
\hline \multicolumn{7}{|c|}{ c Mean values. } \\
\hline \multicolumn{7}{|l|}{ d ANOVA. } \\
\hline \multicolumn{7}{|l|}{ Chi square. } \\
\hline
\end{tabular}


important reasons for nonuse or discontinuation of oral pills in other countries [12, 13]. In Kuwait, a majority of those who disapproved of OCP use were concerned with the side effects of this method.

The percentage of couples using withdrawal increased from only $2 \%$ in 1987 to $11 \%$ in 1999 , and condom use increased from about 4 to $6 \%$. Increased participation by males in fertility planning is an important sign of change and future fertility control efforts in Kuwait. Withdrawal is a well-known method that was used during the days of Prophet Muhammad. There is a considerable consensus among contemporary Muslim scholars that this form of contraception is allowed in Islam [14]. In some Muslim countries such as Turkey, about half of all users employ traditional methods, especially withdrawal, and consider it as effective as modern methods [15]. A similarly high percentage $(43 \%)$ of current users in Bahrain reported that they were using withdrawal in 1995 [16]. Despite the apparently high use of withdrawal in some countries, there is a dearth of research on the current practice, acceptability, use-effectiveness, and safety of this method [17].

Breast-feeding has also gained importance and was reported as a method by $6 \%$ of the current users in 1999 . The above trend may be attributed to the renewed emphasis on breast-feeding by the Ministry of Health in Kuwait. Special initiatives aimed at encouraging breast-feeding have been launched in collaboration with WHO. As part of such efforts, women are also made aware of the beneficial contraceptive effects of regular breast-feeding. Hence, both the awareness and practice of breast-feeding as a contraceptive method seem to have increased.

Various developmental transitions that are occurring in Kuwait have aided the observed changes in fertility control behavior. Multivariate analysis indicated that current contraceptive prevalence was significantly higher among couples who were better educated and lived in urban areas. The educational level of the husband as well as the wife significantly affected current use. In addition to the above characteristics, the husband's opinions had a significant impact on contraceptive use. Current use was about 4 times higher among couples where the husband approved of contraception than the ones where he did not (table 3). Also, current use was especially high among couples where the husband wanted fewer children than the wife. Studies from several countries report that the husband's attitude is a very strong determinant that facilitates or inhibits contraceptive use [18-20].

Preference for current use of various methods differed according to the sociodemographic characteristics of respondents. Modern methods such as the condom were used by the most highly educated urban couples among whom all the husbands approved of contraception. Pills were used by larger percentages of the younger women and the ethnically more traditional Bedouin women. The educational level of IUCD users was higher than that of pill users. Users of traditional methods had significantly lower parity than users of other methods. Despite the above differences in user characteristics, the average number of living children borne by the various groups did not differ significantly, and ranged from 4.34 to 4.64. Additional analysis that examines the contraceptive history and method switching over the reproductive life is necessary to accurately understand respondent preferences for given methods and their reasons for continuing or discontinuing a method.

Despite the increase in the use of condoms and withdrawal, contraception in Kuwait is still mainly the wife's responsibility. The use of withdrawal has not increased to the level in Turkey [15] or Bahrain [16]. Culturally, the home and the children are the woman's prime focus, even though many women are now in the labor force. Women draw their power and salience from children, and in particular from sons. Since fertility is defined as the wife's domain, spacing or limiting children is also seen as women's concern. In a setting like Kuwait, continued and easy accessibility of OCPs and IUCDs as well as other female methods is therefore important for meeting the reproductive planning needs of Kuwait women. At present, OCPs may be obtained free of charge through the government health facilities, or over-the-counter without prescription or a medical checkup. Our analysis suggests that a certain amount of misinformation exists regarding the fertilityinhibiting impact of OCPs and a concern about side effects is expressed by a majority of those who do not approve of pill use. Correct information about the reversibility of the method and side effects needs to be communicated through health care providers and the mass media.

Contraceptive use has had a rather limited impact on reducing fertility in Kuwait. The average fertility of current users in our survey was 4.5 children, while the completed average family size for current users aged 40-49 was 6.26 children. A major reason for the persistence of high fertility is the continued desire for a large number of children, which stood at an average of 5.5 children desired by married women in out study. Among the older and relatively more traditional couples, desired family size has been reported to be even higher [21].

Contraception among Kuwaitis is used largely for spacing children, and limiting the number becomes a consid- 
eration for an average couple only after 5-6 children. A majority of couples, however, initiate contraceptive use after the first or second child. Spacing for health reasons is widely supported by the family and the health system, which provides services and supplies free of charge to Kuwaiti nationals. Their relatively early initiation of such behavior in a couple's reproductive life indicates that the norms favoring contraception are now fairly widespread. Also, contraceptive demand spans a fairly long duration in a couple's reproductive life since they resort mainly to temporary methods. Permanent methods consisting of female or male sterilization do not have much cultural or medical support in Kuwait. In fact, knowledge of these permanent methods is fairly limited. Unlike the knowledge of OCPs and IUCDs that was reported by almost all women, only $55 \%$ had ever heard of female sterilization and $15 \%$ of male sterilization.

\section{Conclusion}

The prevalence of the use of contraceptives has increased to a relatively high level and more than half of all Kuwaiti women reported current use of a method in 1999, with three fourths using a modern one. Male participation in fertility control seems to have increased, especially in terms of traditional methods, i.e., withdrawal. The popularity of oral pills has declined and may be related to misperceptions about or experience of side effects. A majority of methods are used for temporary spacing between children and the average fertility of Kuwaiti couples is still higher than 4 children. Women continue to carry the major responsibility of fertility control and changes in their socioeconomic level are likely to be a major determinant of future contraceptive use patterns. However, a husband's views on family size and contraception may be an even stronger predictor of future fertility control behavior.

\section{Acknowledgments}

This paper is based on grant number KFAS-96-07-15 from the Kuwait Foundation for the Advancement of Sciences (KFAS).

\section{References}

1 Courbage Y: Economic and political issues of fertility transition in the Arab world: Answers and open questions. Popul Environ 1999;20: 353-380.

2 Gezairy HA: Demographic and Health Indicators for Countries of the Eastern Mediterranean. WHO, Regional Office of the Eastern Mediterranean, 1997.

3 Faour M: Fertility policy and family planning in the Arab countries. Stud Fam Plann 1989; 20:254-263.

4 Farid S: Transitions in Demographic and Health Patterns in the Arab Region. Cairo, International Union for the Scientific Study of Population/CDC Press, 1996.

5 Farid S: Family planning, health and family well-being in the Arab world. Arab Popul Conf, Meet Senior Officials, April 1993.

6 Ministry of Public Health: The Kuwait Health Survey, 1984-85. Kuwait, Department of Planning and Follow-Up, Ministry of Public Health, 1987.

7 Al-Rashoud R, Farid S (eds): Kuwait Child Health Survey, 1987. Kuwait, Ministry of Health, 1991.
8 Al-Rashoud R, Farid S (eds): Kuwait Family Health Survey, 1996. Kuwait, Ministry of Health/Riyadh, Council of Ministers of GCC, 1997.

9 Shah NM: Emigration dynamics in Southa Asia: An overview; in Appleyard R (ed): Emigration Dynamics in Developing Countries. Aldershoot, Brookfield/Singapore, Ashgate, 1998, vol II: South Asia, pp 17-29.

10 Shah NM: Trends, Patterns and Predictors of Fertility of Kuwaiti Women. Author survey, 1999.

11 Zurayk H, Sholkamy H, Younis N, Khattab H: Women's health problems in the Arab world: A holistic policy perspective. Int J Gynecol Obstet 1997;58:13-21.

12 Rahman M, Khan MA, Caldwell BK, Kane TT: Factors associated with reported sideeffects of oral pills and injectables in rural Bangladesh; in Thomas T, Kane TT, Barkat-e-Khuda Phillips JF (eds): Reproductive Health in Rural Bangladesh: Policy and Programmatic Implications. ICDDRB monograph no. 7, International Centre for Diarrhoeal Disease Research, Dhaka, Bangladesh 1997, vol 1, pp 191-216.

13 Darney PD: OC practice guidelines: Minimizing side effects. Int J Fertil Womens Med Suppl 1997;1:158-169.
14 State Information Service: Islam's Attitude towards Family Planning. Cairo, Ministry of Waqfs and Ministry of Information, 1994.

15 Goldberg HI, Toros A: The use of traditional methods of contraception among Turkish couples. Stud Fam Plann 1994;25:122-128.

16 Ministry of Health: Bahrain Family Health Survey. Bahrain, Ministry of Health/Riyadh, Council of Ministers of GCC, 1995.

17 Rogow D, Horowitz S: Withdrawal: A review of literature and agenda for research. Stud Fam Plann 1995;26:140-153.

18 Warren CW, Hiyari F, Wingo PA, Abdel-Aziz AM, Morris L: Fertility and family planning in Jordan: Results from the 1985 Jordan husband's fertility survey. Stud Fam Plann 1990; 21:33-39.

19 Mahmood N: Reproductive goals and family planning attitudes in Pakistan: A couple-level analysis. Pakistan Dev Rev 1998;37:19-34.

20 Kamal N: The influence of husbands on contraceptive use by Bangladeshi women. Health Policy Plan 2000;15:43-51.

21 Shah NM, Shah MA, Radovanovic Z: Patterns of desired fertility and contraceptive use in Kuwait. Int Fam Plann Perspect 1998;24:133138. 